\title{
Effects of Nitrate, Nitrite and Diphenylamine on the Photosynthetic Apparatus of Rhodopseudomonas sphaeroides $\mathbf{f}$. sp. denitrificans
}

\author{
By WOJCIECH P. MICHALSKI, ${ }^{1}$ D. J. D. NICHOLAS ${ }^{1 *}$ AND \\ F. R. WHATLEY ${ }^{2}$ \\ ${ }^{1}$ Department of Agricultural Biochemistry, Waite Agricultural Research Institute, \\ University of Adelaide, Glen Osmond, South Australia 5064 \\ ${ }^{2}$ School of Botany, University of Oxford, $U K$
}

(Received 4 February 1985)

\begin{abstract}
We have compared the effect of diphenylamine (DPA) on the pigment composition of Rhodopseudomonas sphaeroides $\mathrm{f}$. $\mathrm{sp}$. denitrificans grown in photoheterotrophic culture with the previously reported effect of nitrate. It was demonstrated that the effect of nitrate is due to the nitrite which is produced during denitrification. Both nitrite and DPA caused a decrease in the synthesis of spheroidene, and the accumulation of more-reduced precursors not normally seen. Nitrate (effectively nitrite) caused a decrease in the amount of bacteriochlorophyll, and the reaction centre from denitrifying cells did not contain the $28 \mathrm{kDal}$ polypeptide $(\mathrm{RC}-\mathrm{H})$ subunit. These effects did not occur over a range of DPA additions ( 4 to $8 \mu \mathrm{g} \mathrm{ml}^{-1}$ ) to cells growing in the absence of nitrate. Denitrifying cells also had $40-50 \%$ lower activity of $\delta$-aminolaevulinic acid synthase than those grown with or without DPA. Both nitrite and DPA treatments resulted in the loss of the B870 light-harvesting complex because of a failure to synthesize its $12 \mathrm{kDal}$ polypeptide subunit.
\end{abstract}

\section{INTRODUCTION}

The denitrifying phototrophic bacterium Rhodopseudomonas sphaeroides $\mathrm{f}$. $\mathrm{sp}$. denitrificans can grow in the light under anaerobic conditions or in the dark under aerobic conditions. In the dark it can also generate ATP by nitrate respiration (Satoh, 1981; Kelley et al., 1982; Michalski \& Nicholas, 1984). The presence of nitrate in a photosynthetically grown bacterial culture induces the synthesis and expression of the activities of nitrate, nitrite and nitrous oxide reductases, accompanied by a drastic decrease of carotenoid and bacteriochlorophyll (Bchl) contents (Michalski \& Nicholas, 1984).

The photosynthetic apparatus of $R$. sphaeroides $\mathrm{f}$. sp. denitrificans, which includes the reaction centre (RC) and light-harvesting ( $\mathrm{LH})$ complex components (B800-850 and B870), is very similar to that of $R$. sphaeroides wild-type (Glazer, 1983; Michalski \& Nicholas, 1984). There is no definitive biochemical evidence about the way in which pigment-protein complexes are organized into photosynthetic units. Spectroscopic measurements indicate the pathway of energy transfer to be $\mathrm{B} 800-850 \rightarrow \mathrm{B} 870 \rightarrow \mathrm{RC}$, and suggest a 'lake' arrangement for these complexes; B870 complexes are situated nearest to the RC, with B800-850 antenna complexes situated peripherally (Monger \& Parson, 1977).

All three components of the photosynthetic unit contain carotenoids. The carotenoids not only protect the photosynthetic apparatus from photo-oxidative damage (Codgell et al., 1976) but also contribute to the harvesting of light energy between 400 and $550 \mathrm{~nm}$. Biosynthesis of

Abbreviations: Bchl, bacteriochlorophyll; DPA, diphenylamine; LH-complex, light-harvesting complex; LDAO, $N, N$-dimethyldodecylamine- $N$-oxide; LDS, lithium dodecyl sulphate; PMSF, phenylmethylsulphonyl fluoride; RC, photochemical reaction centre; TLCK, N $\alpha$-p-tosyl-L-lysine chloromethyl ketone; TPCK, L-1tosylamide-2-phenylethylchloromethyl ketone; ALA, $\delta$-aminolaevulinic acid. 
carotenoids has been extensively studied in $R$. sphaeroides. The formation of spheroidene, the major carotenoid in $R$. sphaeroides f. sp. denitrificans (Michalski \& Nicholas, 1984), is believed to involve phytofluene, $\zeta$-carotene and neurosporene as intermediate metabolites (Goodwin, 1980).

Diphenylamine (DPA) has been reported to be a potent inhibitor of carotenoid synthesis in photosynthetic bacteria. The suppression by DPA of normal carotenoid synthesis is accompanied by a massive intracellular accumulation of the more saturated polyenes, which are not detectable in normal cells (Goodwin \& Osman, 1952; Goodwin, 1956; Cohen-Bazire \& Stanier, 1958). In this paper, using DPA-treated cells as a non-physiological control for comparison with cells grown in the presence of nitrate (effectively nitrite), we show that the two treatments cause similar but not identical changes in the photosynthetic apparatus of $R$. sphaeroides $\mathrm{f}$. sp. denitrificans.

\section{METHODS}

Organism and growth conditions. Rhodopseudomonas sphaeroides f. sp. denitrificans strain IL 106 was kindly supplied by Dr T. Satoh (Department of Biology, Faculty of Science, Tokyo Metropolitan University, Tokyo 158, Japan). R. sphaeroides NCIB 8523 wild-type (strain 2.4.1) was obtained from the National Collection of Industrial Bacteria, Aberdeen, Scotland, UK. Cells were grown $(5 \%, \mathrm{v} / \mathrm{v}$, inoculum) in liquid culture (Satoh et al., 1976) with modifications as described previously (Kelley et al., 1982). DL-Malate (21.4 mM) and $\mathrm{NH}_{4} \mathrm{Cl}(12 \mathrm{mM})$ were included as carbon and nitrogen sources, respectively.

Cells of both strains were grown photoheterotrophically at $30^{\circ} \mathrm{C}$ under anaerobic conditions in completely filled screw-cap bottles, illuminated with $5000 \mathrm{~lx}$ white light $\left(7.35 \mathrm{~W} \mathrm{~m}^{-2}\right)$. Cell growth was monitored by measuring $\mathrm{OD}_{660}$. Dry weights were determined as described previously (Hillmer \& Gest, 1977). When cells were grown in the presence of DPA an appropriate amount of DPA dissolved in ethanol $\left(2.5 \mathrm{mg} \mathrm{ml}^{-1}\right)$ was added to the culture medium immediately before inoculation.

Protein labelling with radioisotopes. Pulse-chase labelling of cell proteins with ${ }^{14} \mathrm{C}$-labelled amino acids was done as described previously (Michalski \& Nicholas, 1984). [U-14 $\mathrm{C}]$ Protein hydrolysate $(10 \mu \mathrm{Ci}$; Amersham), specific activity $50 \mathrm{mCi}$ (mg-atom carbon) $)^{-1}\left[1.85 \mathrm{GBq}\left(\mathrm{mg}\right.\right.$-atom carbon) $\left.{ }^{-1}\right]$, was added to anaerobic suspensions of washed cells $(20 \mathrm{ml}$, sparged with argon) grown photosynthetically in the presence or absence of nitrate or DPA. After $5 \mathrm{~min}$ incubation $\left(30^{\circ} \mathrm{C}\right.$, in the light), $4 \mathrm{ml}$ Casamino acids (casein, acid hydrolysate; $\left.2 \mathrm{mg} \mathrm{ml}^{-1}\right)$ was added to the cell suspensions and incubation continued for a further 5 or $15 \mathrm{~min}$. Then chloramphenicol $\left(10 \mu \mathrm{g} \mathrm{m}^{-1}\right)$ was added, and the cells were harvested immediately and washed in $20 \mathrm{mM}$-potassium phosphate buffer, $\mathrm{pH} 7 \cdot 4$.

Preparation of RC- and LH-complexes. The chromatophore fraction of $R$. sphaeroides $\mathrm{f}$. $\mathrm{sp}$. denitrificans was prepared by the method of Barret et al. (1978). The RCs were extracted from chromatophore membranes by mild treatment with LDAO at $25^{\circ} \mathrm{C}(\mathrm{pH} \mathrm{7.5)}$, as described by Jolchine \& Reiss-Husson (1974). The LH polypeptides were isolated by preparative PAGE in the presence of LDS at $4{ }^{\circ} \mathrm{C}$, as described by Broglie et al. (1980). Electrophoretically separated LH-complexes were extracted from gel slices by homogenization in $50 \mathrm{~mm}$ Tris/glycine buffer. LH-complex polypeptides were then separated by SDS-PAGE. All operations were done in the dark at $4{ }^{\circ} \mathrm{C}$. All buffers contained the protease inhibitors PMSF, TLCK and TPCK (Sigma; all $0.5 \mathrm{~mm}$ ).

Electrophoresis. Discontinuous electrophoresis was done in the presence of $0.1 \%(w / v)$ SDS on slab polyacrylamide gels according to the method of Laemmli \& Favre (1973). The ${ }^{14} \mathrm{C}$-labelled chromatophore fraction was solubilized as described by Chory \& Kaplan (1983). The location of electrophoretically separated ${ }^{14} \mathrm{C}$ labelled proteins was determined by fluorography (Bonner \& Laskey, 1974) on Cronex Hi-plus (Du Pont) intensifying screens. Bacterial proteins separated by electrophoresis were calibrated against low molecular weight protein standards (Pharmacia electrophoresis calibration kit). The proteins were stained with Coomassie brilliant blue R250.

Analysis of pigments. Bchl extracted by acetone/methanol $(7: 2, \mathrm{v} / \mathrm{v})$ from washed cell suspensions was analysed spectrophotometrically $\left(\varepsilon_{772}=76 \mathrm{~mm}^{-1} \mathrm{~cm}^{-1}\right.$, Cohen-Bazire et al., 1957). Carotenoid pigments were extracted from washed cell suspensions with acetone/methanol (1:1, v/v) (Cogdell et al., 1976). Individual carotenoids were separated by TLC on Eastman Kodak silica gel sheets (containing fluorescein) with the following solvents: benzene/chloroform $(1: 1, \mathrm{v} / \mathrm{v})$ (spheroidene, spheroidenone, neurosporene), light petroleum (boiling range 40$60{ }^{\circ} \mathrm{C}$ ) (phytofluene $\left.R_{F}, 0.12\right)$ or benzene/light petroleum $(1: 1, \mathrm{v} / \mathrm{v})$ ( $\zeta$-carotene, phytofluene $R_{F} 0.93$ ). For quantitative analysis of individual carotenoids the following extinction coefficients were used: spheroidene, $\varepsilon_{453}=1.49 \times 10^{5} \mathrm{M}^{-1} \mathrm{~cm}^{-1} ;$ spheroidenone, $\varepsilon_{483}=1.29 \times 10^{5} \mathrm{M}^{-1} \mathrm{~cm}^{-1}$; neurosporene, $\varepsilon_{437}=1.69 \times 10^{5} \mathrm{M}^{-1}$ $\mathrm{cm}^{-1}$ (Cogdell et al., 1976); $\zeta$-carotene, $\varepsilon_{400}=1.23 \times 10^{5} \mathrm{M}^{-1} \mathrm{~cm}^{-1}\left(A_{\mathrm{lcm}}^{10} 2270\right.$ at $\left.400 \mathrm{~nm}\right)$; phytofluene, $\varepsilon_{348}=0.73$ $\times 10^{5} \mathrm{M}^{-1} \mathrm{~cm}^{-1}\left(A_{\mathrm{lcm}}^{10} 1350\right.$ at $\left.348 \mathrm{~nm}\right)($ Davies, 1965$)$.

Spectroscopy. Room temperature absorption spectra of pigment extracts were recorded in a Perkin Elmer Lambda 5 spectrophotometer. Low temperature $(77 \mathrm{~K}$ ) spectra of chromatophore fractions and RCs (in $50 \%, w / v$, 
glycerol) were recorded in a Shimadzu multipurpose recording spectrophotometer, model MPS-50L, fitted with low temperature spectroscopy attachments.

Enzyme assays. Nitrate reductase (EC 1.7.99.4) and nitrite reductase (EC 1.7.2.1) activities were assayed spectrophotometrically as described earlier (Michalski \& Nicholas, 1984). Nitrite was measured as described by Nicholas \& Nason (1954). $\delta$-Aminolaevulinic acid synthase (EC 2.3.1.37) activity in a soluble protein fraction (supernatant $144000 \mathrm{~g}, 90 \mathrm{~min}$ ) was assayed according to the method of Yubisui \& Yoneyama (1972).

Protein determination. Protein contents of cell fractions were determined by the method of Bradford (1976), with bovine serum albumin as the protein standard.

\section{RESULTS}

Effects of DPA and nitrate on growth and pigment synthesis in $R$. sphaeroides $f$. sp. denitrificans

The pigment composition of $R$. sphaeroides $\mathrm{f}$. sp. denitrificans is similar to that reported for $R$. sphaeroides when both are grown in the light (Cogdell et al., 1976; Michalski \& Nicholas, 1984).

The addition of DPA to photosynthetically grown cultures of $R$. sphaeroides $\mathrm{f}$. $\mathrm{sp}$. denitrificans resulted in a drastic decrease in carotenoid content (Table 1). The specific inhibition of carotenoid synthesis (by 50-60\%) occurred over a very narrow range of DPA additions $(6-8 \mu \mathrm{g}$ per ml culture) but at these concentrations growth and Bchl synthesis continued at the same rate as in the untreated controls. Higher concentrations of DPA $\left(>10 \mu \mathrm{g} \mathrm{ml}^{-1}\right)$ inhibited cell growth in the early stages (results not shown). The extent to which the Bchl :carotenoid ratio can be modified by growth in the presence of DPA is evident from the absorption spectra of pigment extracts obtained from normal and DPA-treated cells (Fig. 1, spectra $a, b, c$ ). The cells grown photosynthetically in the presence of DPA $\left(8 \mu \mathrm{g} \mathrm{ml}^{-1}\right)$ became pale green, compared with the reddish brown colour of untreated cells.

The addition of nitrate to photosynthetically grown cultures resulted in a decrease (by a half) of both carotenoid and Bchl contents (Table 1; Fig. 1, spectrum d). The rate of growth of cultures was not affected by the addition of nitrate.

The suppression of normal carotenoid synthesis in cells grown with DPA or nitrate was accompanied by an accumulation of the more saturated polyenes, which were almost absent from normal cells (Fig. 1). The major component accumulated was $\zeta$-carotene, accompanied by smaller quantities of phytofluene $(20-28 \%$ and $13 \%$ of total, respectively; Fig. 1, spectra $c, d)$. Quantitative analyses of the extracted polyenes show that the $\zeta$-carotene and phytofluene contents of cells grown in the presence of DPA or nitrate were about ten times those of normal cells.

A rapid synthesis of coloured carotenoids occurred when cells which had been grown in the presence of DPA were washed and resuspended in fresh DPA-free medium (Fig. 2). After 20

Table 1. Effects of various amounts of DPA on carotenoid and bacteriochlorophyll a contents of $R$. sphaeroides $f$. sp. denitrificans

\begin{tabular}{|c|c|c|c|}
\hline \multirow{2}{*}{$\begin{array}{c}\text { DPA added } \\
{\left[\mu \mathrm{g}(\mathrm{ml} \text { culture })^{-1}\right]}\end{array}$} & \multicolumn{2}{|c|}{$\begin{array}{c}\text { Pigment content* } \\
\left.\left[\text { nmol }(m g \text { dry } w t)^{-1}\right)\right]\end{array}$} & \multirow{2}{*}{$\begin{array}{c}\text { Bchl : carotenoid } \\
\text { ratio }\end{array}$} \\
\hline & Carotenoid & Bchl & \\
\hline \multicolumn{4}{|c|}{ Cells grown without nitrate } \\
\hline 0 & $2 \cdot 49$ & $4 \cdot 34$ & $1 \cdot 7$ \\
\hline 4 & $2 \cdot 14$ & $4 \cdot 22$ & $2 \cdot 0$ \\
\hline 6 & 1.47 & $4 \cdot 69$ & $3 \cdot 2$ \\
\hline 7 & $1 \cdot 26$ & $4 \cdot 50$ & $3 \cdot 6$ \\
\hline 8 & 0.87 & 4.65 & $5 \cdot 3$ \\
\hline 10 & 0.81 & $4 \cdot 18$ & $5 \cdot 2$ \\
\hline \multicolumn{4}{|c|}{ Cells grown with nitrate $(20 \mathrm{mM})$} \\
\hline 0 & 0.79 & 1.66 & $2 \cdot 10$ \\
\hline
\end{tabular}

\footnotetext{
* The values are means of two measurements made in each of two separate experiments, and the values agreed within $10 \%$.
} 


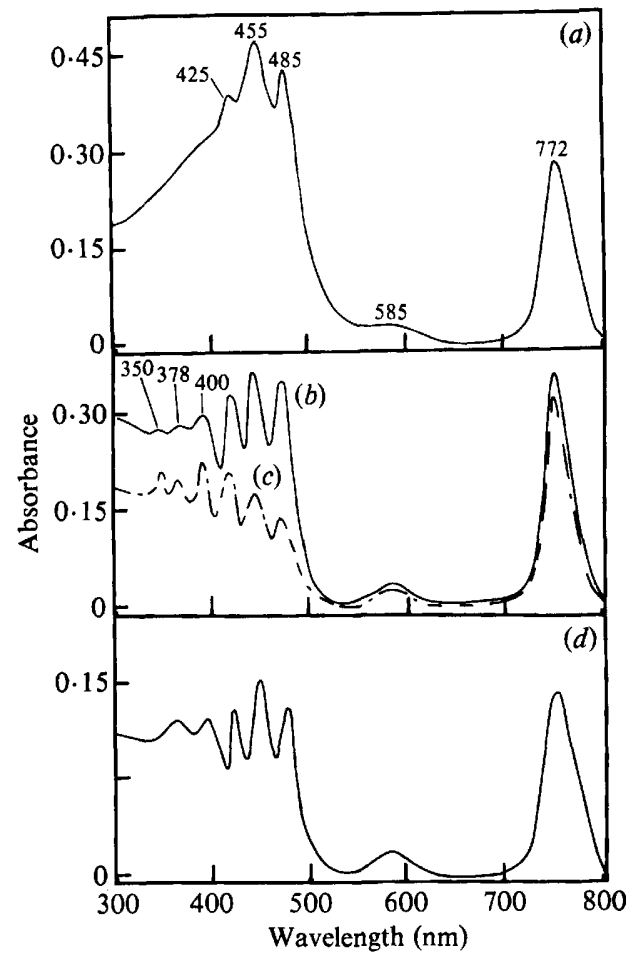

Fig. 1

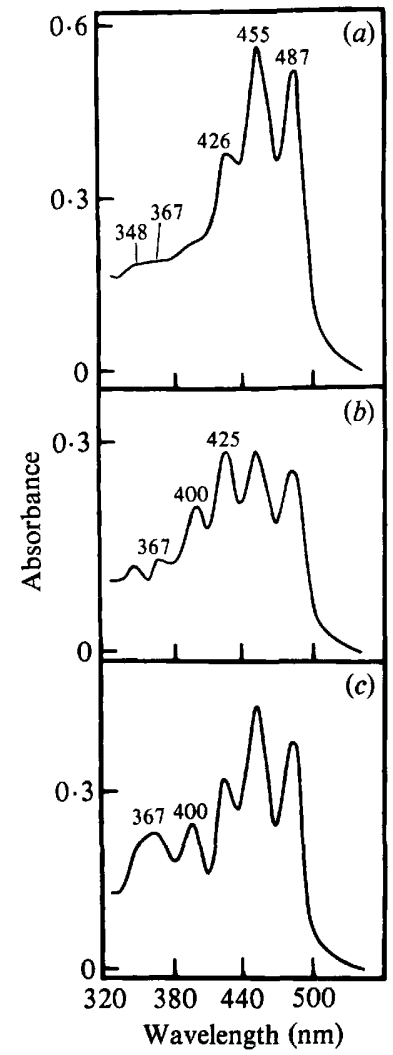

Fig. 2

Fig. 1. Absorption spectra of acetone/methanol extracts prepared from cells grown photoheterotrophically without any additions $(a)$, with $4 \mu \mathrm{g} \mathrm{DPA} \mathrm{m}^{-1}(b)$, with $8 \mu \mathrm{g} \mathrm{DPA} \mathrm{ml}^{-1}(c)$, or with $20 \mathrm{~mm}$-nitrate $(d)$. The table below shows the carotenoid composition of extracts [ $\mathrm{nmol}(\mathrm{mg} \text { dry wt })^{-1}$ ] corresponding to the absorption spectra $(a-d)$. The percentage contribution of individual components to the total carotenoid in each extract is shown in parentheses.

$\begin{array}{ccccc}\text { Extract } & \begin{array}{c}\text { plus } \\ \text { spheroidenone }\end{array} & \text { Neurosporene } & \zeta \text {-Carotene } & \text { Phytofluene } \\ a & 2.04(88) & 0.20(8) & 0.04(2) & 0.05(2) \\ b & 1.61(78) & 0.16(8) & 0.18(9) & 0.10(5) \\ c & 0.51(53) & 0.07(7) & 0.27(28) & 0.12(12) \\ d & 0.56(62) & 0.05(5) & 0.18(20) & 0.12(13)\end{array}$

Fig. 2. Absorption spectra of the carotenoid extracts of cells grown photoheterotrophically without

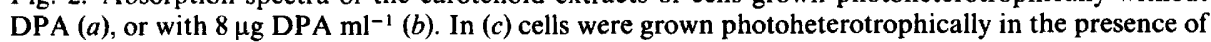
DPA for $12 \mathrm{~h}$, after which they were harvested, washed and transferred into fresh, sterile, DPA-free culture medium for $20 \mathrm{~min}$ in the light at $30^{\circ} \mathrm{C}$. The table below shows the carotenoidcomposition (see Fig. 1) of extracts corresponding to absorption spectra $(a-c)$. Values in parentheses are as in Fig. 1.

$\begin{array}{ccccc}\text { Spheroidene } & & & \\ \text { plus } & \text { Neurosporene } & \zeta \text {-Carotene } & \text { Phytofluene } \\ \text { Extract } & \text { spheroidenone } & 0.18(8) & 0.03(1) & 0.03(1) \\ a & 2 \cdot 15(90) & 0.08(8) & 0.19(20) & 0.11(12) \\ b & 0.58(60) & 0.14(8) & 0.16(9) & 0.10(5)\end{array}$

min incubation in the light the cells contained almost normal amounts of the major carotenoid spheroidene ( $78 \%$ of total) and only small quantities of $\zeta$-carotene and phytofluene $(9 \%$ and $5 \%$ of total, respectively). 


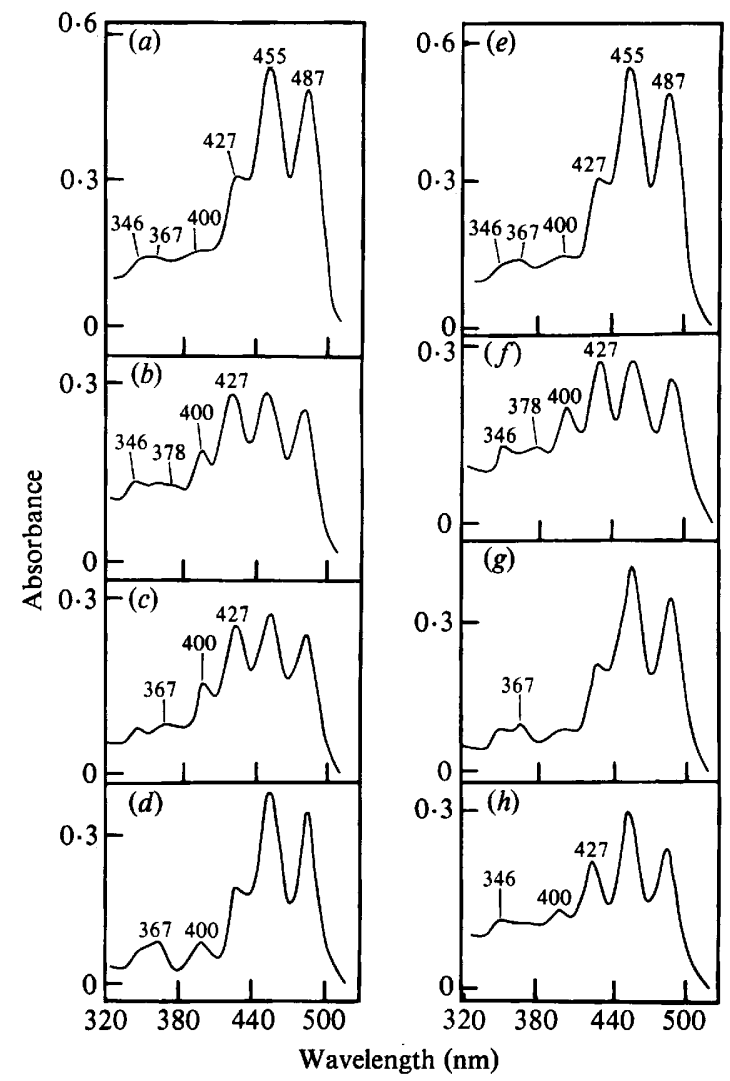

Fig. 3. Absorption spectra of the carotenoids extracted from cells grown photoheterotrophically without DPA $(a, e)$, or with $8 \mu \mathrm{g} \mathrm{DPA} \mathrm{ml}^{-1}(b, f)$. Additionally, cell cultures grown in the presence of DPA were harvested at mid-exponential phase $(12 \mathrm{~h})$, washed and then transferred into sterile DPAfree media containing $1 \mathrm{~mm}$-nitrite or $20 \mathrm{~mm}$-nitrate. Growth of these cultures was then continued for 1 or $3 \mathrm{~h}$ in the presence of nitrite $(c, d)$, or for 3 or $6 \mathrm{~h}$ in the presence of nitrate $(g, h)$. The table below shows the carotenoid composition (see Fig. 1) of extracts corresponding to absorption spectra $(a)-(h)$. Values in parentheses are as in Fig. 1.

$\begin{array}{ccccc}\text { Extract } & \begin{array}{c}\text { Spheroidene } \\ \text { plus } \\ \text { spheroidenone }\end{array} & \text { Neurosporene } & \zeta \text {-Carotene } & \text { Phytofluene } \\ a, e & 2.0(94) & 0.11(5) & 0.02(1) & 0.02(1) \\ b, f & 0.60(57) & 0.06(6) & 0.24(24) & 0 \cdot 14(13) \\ c & 0.65(61) & 0.05(5) & 0.24(22) & 0 \cdot 12(12) \\ d & 1.35(82) & 0.10(6) & 0.09(6) & 0 \cdot 10(6) \\ g & 1.40(84) & 0.07(4) & 0 \cdot 12(7) & 0 \cdot 10(5) \\ h & 0.70(64) & 0.03(3) & 0.23(21) & 0.13(12)\end{array}$

\section{Inhibition of carotenoid synthesis by nitrite}

Although the cells of $R$. sphaeroides $\mathrm{f}$. sp. denitrificans grown under denitrifying conditions produced a large amount of nitrite (up to $10 \mathrm{~mm}$ in approximately 8-10 h after $20 \mathrm{~mm}$-nitrate had been added), they failed to grow photosynthetically when $1 \mathrm{mM}$-nitrite was added to the culture at early growth stages. The addition of nitrite to photosynthetically grown cultures inhibited carotenogenesis (Fig. 3). The synthesis of spheroidene did not occur when cells which had been grown in the presence of DPA $\left(8 \mu \mathrm{g} \mathrm{ml}^{-1}\right)$ were washed and resuspended in DPA-free medium containing 2 mM-nitrite (Fig. $3 c$ c). However, an extensive and rapid synthesis of this carotenoid took place after $3 \mathrm{~h}$ incubation (Fig. $3 d$ ), at which time all the nitrite had been removed by nitrite reductase. 

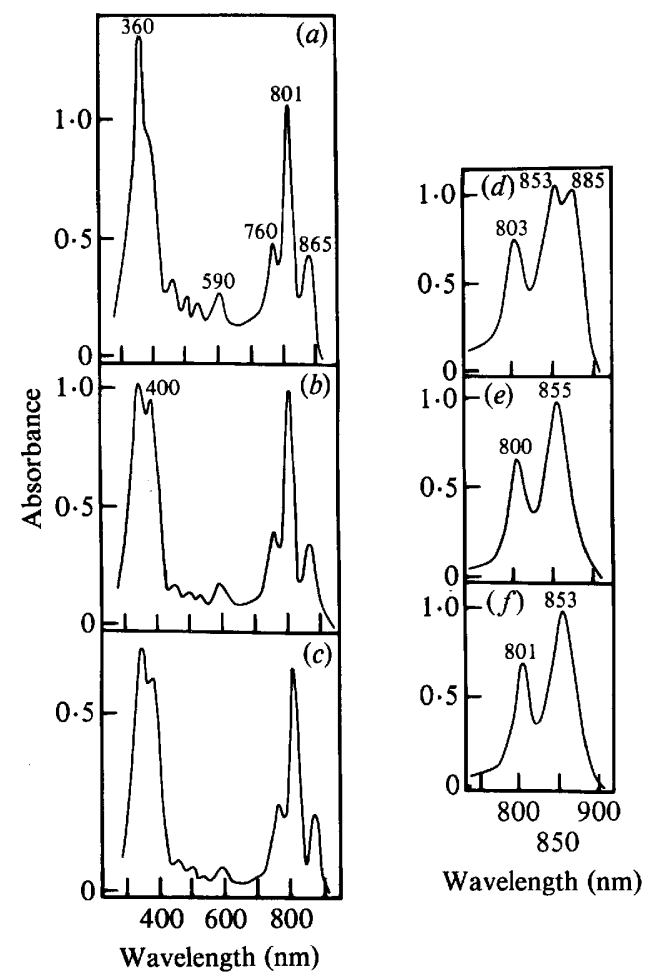

Fig. 4. Low temperature $(77 \mathrm{~K}$ ) absorption spectra of RC-complexes $(a-c)$ and LH-complexes (in chromatophores) $(d-f)$. Chromatophores and RC-complexes were isolated from cells grown photoheterotrophically without any additions $(a, d)$, with $8 \mu \mathrm{g} \mathrm{DPA} \mathrm{ml}^{-1}(b, e)$, or with $20 \mathrm{mM}$-nitrate $(c, f)$.

When DPA-treated cells were washed and resuspended in DPA-free medium containing 20 mM-nitrate, synthesis of carotenoids was not affected during $3 \mathrm{~h}$ incubation in the light (Fig. $3 g$ ). At this time, almost $80 \%$ of the original amount of spheroidene was found in the cells. However, after further incubation ( 4 and $6 \mathrm{~h}$ ), when the concentration of nitrite produced reached approximately $1 \mathrm{mM}$, the synthesis of spheroidene again ceased and $\zeta$-carotene accumulated (Fig. $3 h$, peaks at 425,400 and $378 \mathrm{~nm}$ ). These observations confirm that nitrate does not directly inhibit carotenoid synthesis, but are consistent with the view that nitrite, produced by the activity of nitrate reductase, has a specific inhibitory effect.

\section{Spectral and biochemical characterization of pigment-protein complexes}

In photosynthetic bacteria, the light-absorbing pigments (Bchl and carotenoid) exist in vivo as well-defined RC and light-harvesting antenna protein-pigment complexes (Thornber et al., 1978). $R$. sphaeroides wild-type and $R$. sphaeroides $\mathrm{f}$. $\mathrm{sp}$. denitrificans both contain two antenna complexes, one absorbing maximally at $870 \mathrm{~nm}$, termed the $\mathrm{B} 870$ complex and the other at 800 and $850 \mathrm{~nm}$, termed B800-850; both of these spectral forms of Bchl can be observed in the $77 \mathrm{~K}$, near-IR spectra of chromatophores (peaks 803,853 and $885 \mathrm{~nm}$; Fig. $4 d$ ). The $885 \mathrm{~nm}$ peak (the spectrum of the B870 complex is shifted at low temperature) disappears from spectra of chromatophores of cells grown in the presence of either DPA (Fig. $4 e$ ) or nitrate (Fig. $4 f$ ). In these chromatophores the absorption peaks at $855 \mathrm{~nm}$, relative to those at $800 \mathrm{~nm}$, are also smaller than in normal cells.

Spectral properties of RCs purified by extraction with LDAO from chromatophores of pigment-depleted cells (grown in the presence of DPA or nitrate) are shown in Fig. 4. There were no changes in the near-IR component of the spectra of RC complexes obtained from either untreated or nitrate- or DPA-treated cells (Fig. $4 a, b, c$, respectively). However, absorption 


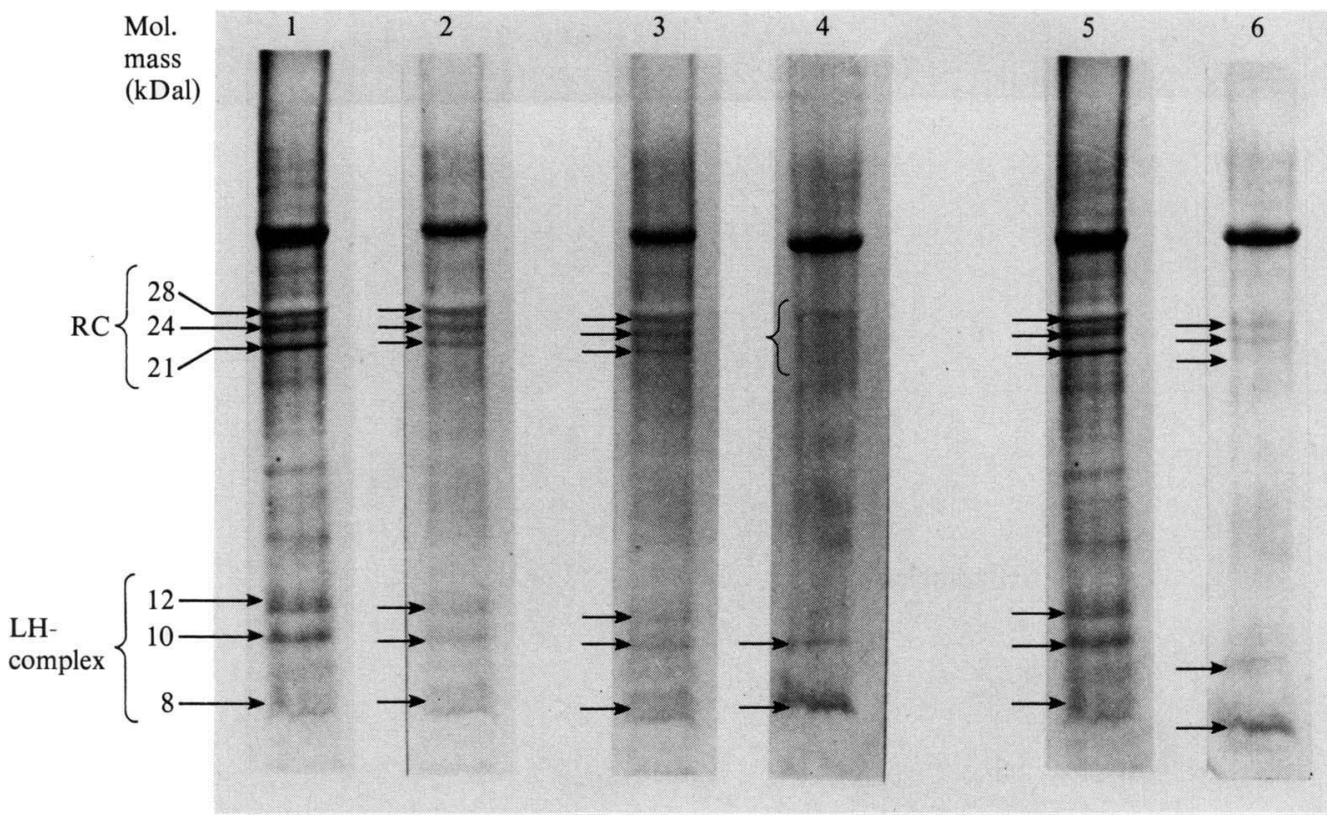

Fig. 5. Autoradiograms of electrophoretically separated RC and LH-complex polypeptides after a 'pulse-chase' labelling of the cells with ${ }^{14} \mathrm{C}$-labelled amino acids for $5 \mathrm{~min}$ (lanes 1 and 2 ) and $15 \mathrm{~min}$ (lanes 3-6). Cells grown photoheterotrophically for $20 \mathrm{~h}$ in the presence of $20 \mathrm{~mm}$-nitrate (lanes 2 and 4), or $8 \mu \mathrm{g} \mathrm{DPA} \mathrm{ml} \mathrm{m}^{-1}$ (lane 6) were harvested, washed and resuspended in nitrate-free, DPA-free medium. These cells were pulse-labelled as described in Methods and the chromatophores were then prepared. Radioactive proteins $(50 \mu \mathrm{g})$ were separated by SDS-PAGE and autoradiographed. Lanes 1,3 and 5 represent the labelling patterns of untreated photoheterotrophically grown cells. All ${ }^{14} \mathrm{C}$-labelled protein samples were diluted so that they contained approximately 40000 c.p.m., which corresponds to approximately $40-60 \mu \mathrm{g}$ protein.

spectra of RC-complexes of cells grown in the presence of nitrate or DPA $\left(8 \mu \mathrm{g} \mathrm{ml}^{-1}\right)$ again indicate that $\zeta$-carotene had accumulated (peak at $400 \mathrm{~nm}$ ). These results show that both types of carotenoid-depleted cells (i.e. cells grown in the presence of DPA or nitrate) lack the B870 LH-complex. It is, however, noteworthy that the yield of the RC-complexes extracted from the chromatophore membranes of cells grown with nitrate was about $30-40 \%$ lower than that of untreated cells.

\section{Biosynthesis of RC-and LH-complex polypeptides in cells grown in the presence of nitrate and $D P A$}

The synthesis of subunits of RC- and LH-complexes was studied by following the incorporation of ${ }^{14} \mathrm{C}$-labelled amino acids into chromatophore proteins, in 'pulse-chase' labelling experiments ( $5 \mathrm{~min}$ labelling followed by a 5 or $15 \mathrm{~min}$ 'chase'). Fig. 5 shows autoradiograms of electrophoretically separated ${ }^{14} \mathrm{C}$-labelled chromatophore proteins. After a 5 and 15 min 'pulse-chase' labelling, six major polypeptides identified as RC- and LH-complex subunits had been synthesized in cells grown in the light (Fig. 5a,c,e). After 15 min 'pulse-chase' labelling of cells grown in the presence of nitrate, subunits of the RC were much less intensively labelled, and no sharp protein bands could be identified in the autoradiogram even after a longer exposure period (Fig. 5d). All three subunits of the RC-complex in cells grown in the presence of DPA were labelled, although the intensity was less than that in control cells (Fig. $5 e, f$ ). The 10 $\mathrm{kDal}$ subunit of $\mathrm{LH}$-complexes of cells grown with either nitrate (effectively nitrite) or DPA was less intensively labelled than in control cells. In LH-complexes of the treated cells no $12 \mathrm{kDal}$ polypeptide was present (Fig. $5 d, f$ ). Since the $12 \mathrm{kDal}$ polypeptide is a subunit only of the $\mathrm{B} 870$ LH-complex, these results support the conclusion that nitrite produced during dentrification, as well as DPA, inhibits synthesis and/or assembly of this particular pigment-protein complex. 

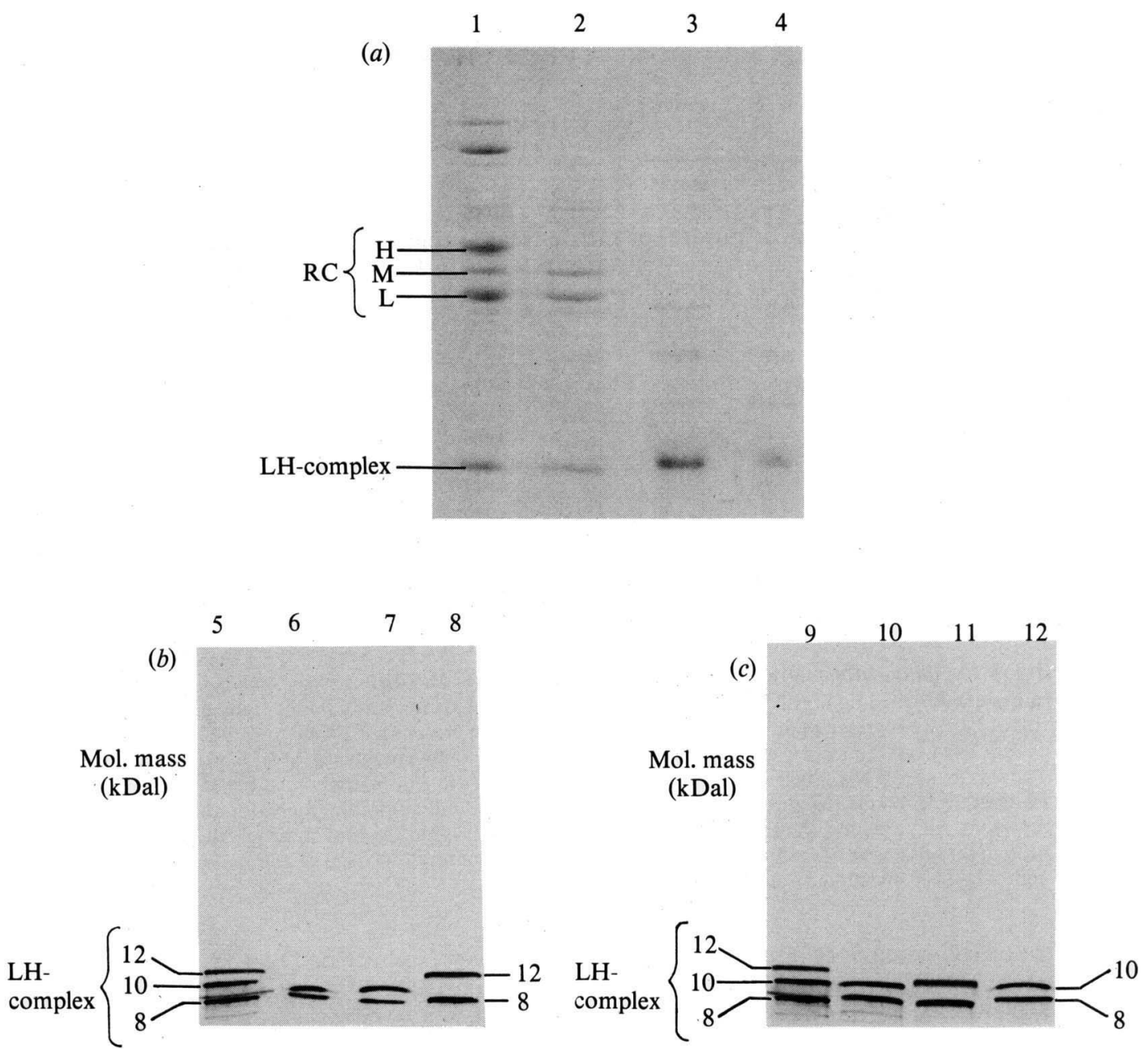

Fig. 6. Polypeptide composition of RC- and LH-complexes. (a) LDS-PAGE at $4{ }^{\circ} \mathrm{C}$ on a $7 \cdot 5-15 \%$ gradient gel of chromatophores ( $160 \mu \mathrm{g}$ protein containing $15 \mu \mathrm{g} \mathrm{Bchl}$ ) from cells grown without nitrate (lane 1), or with $20 \mathrm{~mm}$-nitrate (lane 2). The LH-complex polypeptides were extracted from lanes 1 and 2 and re-run on LDS-PAGE gels (lanes 3 and 4 respectively). $\mathrm{H}, \mathrm{M}$ and $\mathrm{L}$ are RC subunits of apparent molecular mass 28,24 and $21 \mathrm{kDal}$ respectively. $(b, c)$ SDS-PAGE of LH-complex polypeptides on a 10 $17 \%$ gradient gel $(30 \mu \mathrm{g}$ protein in each sample). Lanes 5 and 9 , total LH-complex polypeptide extracted from lane 3. Lanes 6 and 7, duplicate samples of the B800-850 complex polypeptides; lane 8, B870 complex; both complexes were prepared by LDS-PAGE according to Broglie et al. (1980). Lanes 10, 11 and 12, LH-complex polypeptides separated from chromatophores of cells grown with nitrate, nitrite and DPA respectively.

\section{Polypeptide composition of $R C$ - and LH-complexes in chromatophores of cells grown in the presence of nitrate or diphenylamine}

Substitution of LDS for SDS in Laemmli-type electrophoresis enables solubilization and electrophoresis to be done at $4{ }^{\circ} \mathrm{C}$. The separation of polypeptides from the chromatophore membrane preparations (preheated in boiling water for $90 \mathrm{~s}$ ) is shown in Fig. 6(a). In the presence of LDS, the RC of normal cells (Fig. $6 a$ lane 1), as well as those treated with DPA (not shown), dissociated into three subunits with apparent molecular masses of 28,24 and $21 \mathrm{kDal}$ (subunits H, M, L, respectively). The RC in chromatophores of denitrifying cells, however, lacked a $28 \mathrm{kDal}$ subunit (Fig. $6 a$, lane 2). 
Although the LH-complex polypeptides were well separated from RC subunits, they could not be fully resolved in this system. Therefore, they were extracted from gel slices, purified on similar LDS-gels (Fig. $6 a$, lanes 3 and 4), then extracted again and characterized by SDS-PAGE on $10-17 \%(\mathrm{w} / \mathrm{v})$ gradient slab gels. The LH-complex from normal cells (Fig. 6a, lane 1) was separated into three polypeptides of apparent molecular masses 12,10 and $8 \mathrm{kDal}$ (Fig. $6 b$, lane 5), representing subunits of B870 (12 and $8 \mathrm{kDal}$; Fig. $6 b$, lane 8 ) and B800-850 (10 and $8 \mathrm{kDal}$; Fig. $6 b$, lanes 6 and 7). As shown in Fig. 6(c), complete LH-complexes from chromatophores prepared from either DPA- or nitrate- or nitrite-treated cells lacked the $12 \mathrm{kDal}$ polypeptide (Fig. $6 c$, lanes 10, 11 and 12 respectively). Since this particular polypeptide is a subunit only of the B870 LH-complex, these results support the conclusion that nitrite (produced by denitrification of nitrate or added directly), as well as DPA, inhibits synthesis and/or assembly of this LH-complex (cf. Fig. 5).

\section{DISCUSSION}

The structural and biochemical properties of $R$. sphaeroides $\mathrm{f}$. sp. denitrificans IL 106 resemble those of $R$. sphaeroides wild-type (Satoh et al., 1976; Michalski \& Nicholas, 1984). In both organisms the photosynthetic apparatus contains an RC as well as the two Bchl-protein complexes (B800-850 and B870) of the light-harvesting system. Spheroidene was a major carotenoid component of the photosynthetic membranes. DPA, a potent inhibitor of carotenoid synthesis in many organisms (Goodwin, 1980), inhibited the formation of spheroidene in $R$. sphaeroides f. sp. denitrificans (Table 1). By contrast, DPA at similar concentrations inhibited the growth of $R$. sphaeroides wild-type but without any differential effect on pigmentation (cf. Goodwin, 1956).

As reported by Michalski \& Nicholas (1984), the inclusion of nitrate in cultures of $R$. sphaeroides $\mathrm{f}$. sp. denitrificans grown photoheterotrophically resulted in a drastic decrease in both Bchl and carotenoid contents. We now show that the decrease in the formation of carotenoids in these cultures is due to nitrite, a product of nitrate reduction. The synthesis of carotenoids (mainly spheroidene) was restored when DPA-treated cells were washed, transferred to DPAfree medium and then incubated in light in the absence of nitrite (Fig. 3). Since the inhibition of carotenoid synthesis by either DPA or nitrite resulted in an accumulation of $\zeta$-carotene (Figs 1 and 2) it is clear that both compounds inhibit the enzymic desaturation of $\zeta$-carotene to neurosporene, one of the precursors of spheroidene (Goodwin, 1980).

The decrease in carotenoid content of cells grown in the presence of either DPA or nitrate (effectively the reduction product, nitrite) is accompanied by structural changes in the photosynthetic apparatus. Both types of cells lack LH-complex B870 (Figs 4-6) and do not synthesize one of the three subunits (12 kDal polypeptide) needed for this pigment-protein complex (Fig. 6).

The decrease in Bchl and carotenoid contents in cells grown in the presence of nitrate is also accompanied by a limited formation of RC-complexes. These cells contained fewer chromatophores and the number of RC complexes was about $60 \%$ of that in untreated cells.

Although the results that we obtained on the effect of DPA and nitrite are consistent with the proposal that the enzymic desaturation of $\zeta$-carotene (possibly a single enzyme reaction) is inhibited, the fact that cells grown in the presence of nitrate have smaller amounts of Bchl, RCcomplexes and lack the $28 \mathrm{kDal}$ and $12 \mathrm{kDal}$ polypeptide subunits, whereas DPA-treated cells have normal amounts of $\mathrm{Bchl}$ yet also lack the $12 \mathrm{kDal}$ subunit, indicates that this simple explanation thay be insufficient. $\delta$-Aminolaevulinic acid (ALA) synthase, which produces 5aminolaevulinic acid from glycine and succinyl-CoA, is a key enzyme in the synthesis of tetrapyrroles, the reaction common to the biosynthesis of Bchl and haem. Experiments in vivo, as well as with purified enzyme preparations, have shown that several factors are involved in photopigment synthesis at this step; light intensity, oxygen pressure, ATP, Mg-protoporphyrine and haem (Jones, 1978). We have measured the ALA synthetase activity in the soluble protein fraction of cells grown under various conditions. Highly active enzyme was found in both normal and DPA-treated cells [4.3 and $4.0 \mathrm{nmol}$ ALA formed $\min ^{-1}$ (mg protein) ${ }^{-1}$, respectively]. However, in denitrifying cells, the enzyme activity was decreased by 
approximately a half $\left[2.4 \mathrm{nmol} \min ^{-1}(\mathrm{mg} \text { protein })^{-1}\right]$. These results, based on several independent experiments, confirm a drastic reduction in soluble cytochrome content of cells grown in the presence of nitrate (W. P. Michalski, D. J. Miller \& D. J. D. Nicholas, unpublished results). Thus, we can now offer a plausible explanation for the similar effect of nitrate, nitrite and DPA on carotenogenesis, as well as their differential effects on Bchl formation.

RC- and LH-complexes from chromatophores of denitrifying cells lack the $28 \mathrm{kDal}$ and 12 kDal polypeptide subunits, respectively (Fig. 6). Since the protease inhibitors PMSF, TLCK and TPCK were included in all buffers, the polypeptide compositions of RC-and LH-complexes were not due to proteolytic action, but rather to the inhibition of their synthesis and/or assembly. It is also noteworthy that two smaller subunits ( 24 and $21 \mathrm{kDal})$, which remain associated in the $\mathrm{RC}$-complex of denitrifying cells, were photochemically active at room temperature (see spectra in Fig. 4 and cf. Okamura et al., 1974).

In conclusion, it is still not clear, however, whether the carotenoid deficiency is itself responsible for the failure to synthesize the $12 \mathrm{kDal}$ subunit, so that the self-assembly of the light-harvesting components (Sistrøm et al., 1956) is prevented by the absence of one or more essential components. It remains to be established whether nitrite and DPA primarily affect the synthesis of the $12 \mathrm{kDal}$ subunit, in which case a feed back mechanism might come into operation to control extra carotenoid synthesis (Segen \& Gibson, 1971) or Bchl synthesis (Lascelles \& Hatch, 1969) when this polypeptide is missing. It is unlikely that the $12 \mathrm{kDal}$ subunit is the primary target in view of the known effects of DPA on carotenoid biosynthesis in a variety of photosynthetic and non-photosynthetic organisms (Goodwin, 1980).

The work was supported by a grant to D.J.D. N. from the Australian Research Grant Scheme (ARGS). W.P.M. acknowledges with thanks the award of an ARGS sponsored research associateship. F.R. W. is grateful to the University of Adelaide for a Distinguished Visitor's Award tenable in the Department of Agricultural Biochemistry, May to September, 1984. The technical assistance of D. Mathew is gratefully acknowledged.

\section{REFERENCES}

Barret, J., Hunter, C. N. \& Jones, O. T. G. (1978). Properties of a cytochrome $c$ enriched light particulate fraction isolated from the photosynthetic bacterium Rhodopseudomonas sphaeroides. Biochemical Journal 174, 267-275.

BONNER, W. M. \& LASKey, R. A. (1974). A film detection method for tritium-labelled proteins and nucleic acids in polyacrylamide gels. European Journal of Biochemistry 46, 83-85.

BRADFORD, M. M. (1976). A rapid and sensitive method for the quantitation of microgram quantities of protein utilizing the principle of protein-dye binding. Analytical Biochemistry 72, 248-254.

Broglie, R. M., Hunter, C. N., Delepelaire, P., Niederman, R. A., Chua, N.-H. \& Clayton, R. K. (1980). Isolation and characterization of the pigment-protein complexes of Rhodopseudomonas sphaeroides by lithium dodecyl sulfate/polyacrylamide gel electrophoresis. Proceedings of the National Academy of Sciences of the United States of America 77, 87-91.

Chory, J. \& Kaplan, S. (1983). Light-dependent regulation of the synthesis of soluble and intracytoplasmic membrane proteins of Rhodopseudomonas sphaeroides. Journal of Bacteriology 153, 465-474.

Codgell, J. R., Parson, W. W. \& KerR, M. A. (1976). The type, amount, location and energy transfer properties of the carotenoid in reaction centres in Rhodopseudomonas sphaeroides. Biochimica et biophysica acta 540, 83-93.
Cohen-Bazire, G. \& STANier, R. Y. (1958). Inhibition of carotenoid synthesis in photosynthetic bacteria. Nature, London 181, 250-252.

Cohen-Bazire, G., Sistrøm, W. R. \& Stanier, R. Y. (1957). Kinetic studies of pigment synthesis by nonsulfur purple bacteria. Journal of Cellular and Comparative Physiology 49, 25-68.

DAviES, B. H. (1965). In Chemistry and Biochemistry of Plant Pigments, pp. 489-532. Edited by T. W. Goodwin. London, New York: Academic Press.

Glazer, A. N. (1983). Comparative biochemistry of photosynthetic light-harvesting systems. Annual Review of Biochemistry 52, 125-151.

GoodwIN, T. W. (1956). The carotenoids of photosynthetic bacteria. II. The carotenoids of a number of non-sulfur purple photosynthetic bacteria (Athiorhodaceae). Archiv für Mikrobiologie 24, 313322 .

Goodwin, T. W. (1980). Photosynthetic bacteria. In The Biochemistry of Carotenoids, vol. 1, pp. 321-349. London, New York: Chapman \& Hall.

Goodwin, T. W. \& Osman, H. G. (1953). Studies in carotenogenesis. 9. General cultural conditions controlling carotenoid (spirilloxanthin) synthesis in the photosynthetic bacterium Rhodospirillum rubrum. Biochemical Journal 53, 541-546.

Hillmer, P. \& GeST, H. (1977). $\mathrm{H}_{2}$ metabolism in the photosynthetic bacterium Rhodopseudomonas capsulata. Journal of Bacteriology 129, 724-731.

JolChine, G. \& Reiss-Husson, F. (1974). Comparative 
studies of two reaction centre preparations from Rhodopseudomonas sphaeroides Y. FEBS Letters 40 , 5-8.

JONES, O. T. G. (1978). Biosynthesis of porphyrins, hemes and chlorophylls. In The Photosynthetic Bacteria, pp. 751-777. Edited by R. K. Clayton \& W. R. Sistrøm. New York \& London: Plenum Press.

Kelley, B. C., Dunstan, R. H. \& Nicholas, D. J. D. (1982). Respiratory dependent nitrogenase activity in the dark in the denitrifying phototrophic bacterium Rhodopseudomonas sphaeroides $\mathrm{f}$. sp. denitrificans. FEMS Microbiology Letters 13, 253-258.

LAEMMLI, U. K. \& FAVRE, M. (1973). Maturation of the head of bacteriophage T4. Journal of Molecular Biology 80, 575-579.

Lascelles, J. \& HaTCH, T. P. (1969) Bacteriochlorophyll and heme synthesis in Rhodopseudomonas sphaeroides; possible role of heme in regulation of the branched biosynthetic pathway. Journal of Bacteriology 98, 712-720.

Monger, T. G. \& Parson, W. W. (1977). Singlettriplet fusion in Rhodopseudomonas sphaeroides chromatophores. A probe of the organization of the photosynthetic apparatus. Biochimica et biophysica acta 460, 393-407.

Michalski, W. P. \& Nicholas, D. J. D. (1984). The adaptation of Rhodopseudomonas sphaeroides $\mathrm{f}$. $\mathrm{sp}$. denitrificans for growth under denitrifying conditions. Journal of General Microbiology 130, 155165.

Nicholas, D. J. D. \& NaSON, A. (1954). Molybdenum as an electron carrier in nitrate reductase action. Archives of Biochemistry and Biophysics 51, 311-312.
OKamura, M. Y., Steiner, L. A. \& Feher, G. (1974). Characterization of reaction centers from photosynthetic bateria. I. Subunit structure of the protein mediating the primary photochemistry in Rhodopseudomonas sphaeroides R-26. Biochemistry 13, 1394-1403.

SATOH, T. (1981). Soluble dissimilatory nitrate reductase containing cytochrome $c$ from a photodenitrifier Rhodopseudomonas sphaeroides forma $\mathrm{sp}$. denitrifcans. Plant and Cell Physiology 22, 443-452.

Satoh, T., Hoshino, Y. \& Kitamura, M. (1976). Rhodopseudomonas sphaeroides forma $\mathrm{sp}$. denitrificans, a denitrifying strain as a sub-species of Rhodopseudomonas sphaeroides. Archives of Microbiology 108, 265-269.

Segen, B. J. \& Gibson, K. D. (1971). Deficiencies of chromatophore proteins in some mutants of Rhodopseudomonas sphaeroides with altered carotenoids. Journal of Bacteriology 105, 701-709.

SistrøM, W. R., Griffiths, M. \& Stanier, R. Y. (1956). The biology of a photosynthetic bacterium which lacks coloured carotenoids. Journal of Cellular and Comparative Physiology 4, 473-515.

Thornber, J. P., Trosper, T. L. \& Strouse, C. E. (1978). Bacteriochlorophyll in vivo. Relationship of spectral forms to specific membrane components. In The Photosynthetic Bacteria, pp. 133-160. Edited by R. K. Clayton \& W. R. Sistrøm. New York \& London: Plenum Press.

Yubisui, T. \& YoneYama, Y. (1972). $\delta$-Aminolevulinic acid synthetase of Rhodopseudomonas sphaeroides, purification and properties of the enzyme. Archives of Biochemistry and Biophysics 150, 77-85. 